\title{
POLITITIKK
}

\section{Det nødvendige og det mulige. Aktuelle spændinger i dansk udenrigspolitik}

\author{
Louise Riis Andersen \\ Dansk Institut for Internationale Studier (DIIS)
}

\begin{abstract}
Sammendrag
Valget af Trump og Brexit indskriver sig sammen med Ruslands selvhævdende adfærd og Kinas øgede globale rolle i en udvikling, der set med danske udenrigspolitiske øjne opfattes som mere end almindeligt foruroligende: "De tektoniske plader, som dansk udenrigspolitik har hvilet på i mange år, er i bevægelse", skriver Regeringen i sin Udenrigs- og Sikkerhedspolitiske Strategi 2017/18 (Regeringen 2017a). Artiklen belyser på den baggrund den aktuelle debat om, hvordan Danmark kan og skal agere i en verden, der opfattes som stadigt mere usikker og uforudsigelig. Artiklen fokuserer især på spørgsmålet om, hvorvidt der lægges op til en nytænkning eller blot en justering af Danmarks foretrukne udenrigspolitiske virkemidler og institutionelle forankring. Med afsæt i en analyse af de seneste års strategiske udmeldinger og konkrete udenrigspolitiske tiltag identificerer artiklen et stigende modsætningsforhold mellem retorikken og ressourcerne i dansk udenrigspolitik. Skellet mellem det, der italesættes som udenrigspolitisk nødvendigt og det, der opfattes som indenrigspolitisk muligt, vokser, og som følge heraf fremstår det danske svar på de seneste års bekymrende internationale udvikling indtil videre usammenhængende.
\end{abstract}

Nøgleord: Liberal orden • internationale institutioner • aktivisme • tilpasning $\cdot$ diskursanalyse

Set med danske udenrigspolitiske øjne har de seneste par år været mere end almindeligt foruroligende: "De tektoniske plader, som dansk udenrigspolitik har hvilet på

\footnotetext{
^Korrespondanse: Louise Riis Andersen, epost: lan@diis.dk

(C) 2018 Louise Riis Andersen. This is an Open Access article distributed under the terms of the Creative Commons Attribution 4.0 International License (http://creativecommons.org/licenses/by/4.0/), allowing third parties to copy and redistribute the material in any medium or format and to remix, transform, and build upon the material for any purpose, even commercially, provided the original work is properly cited and states its license.

Citation: Louise Riis Andersen (2018). Det nødvendige og det mulige. Aktuelle spcendinger i dansk udenrigspolitik, 76: 316-330. http://dx.doi.org/10.23865/intpol.v76.1368
} 
i mange år, er i bevægelse”, skriver Regeringen i indledningen til sin Udenrigs- og Sikkerhedspolitiske Strategi 2017/18 (Regeringen 2017a). Det transatlantiske sammenhold og EU's indre sammenhængskraft - ja, faktisk hele det regelbaserede internationale samarbejde og respekten for demokrati og menneskerettigheder - udfordres i disse år af "autoritære, nationalistiske tendenser" (Regeringen 2017a). Geopolitikken og dermed territorialforsvaret er tilbage, mens nye diffuse trusler som cyberangreb og påvirkningskampagner vokser, uden at 'gamle' diffuse trusler fra migration og terrorisme aftager (Regeringen 2017b). Samtidig forskyder det økonomiske tyngdepunkt sig ikke bare mod Asien, men også mod en række nye ikke-statslige aktører, der har ressourcerne, teknologien og viljen til at påvirke den globale udvikling.

Det korte, unipolære øjeblik, der gav Danmark og andre liberalt sindede småstater et hidtil uset stort udenrigspolitisk manøvrerum, er under hastig afvikling, og fremtiden tegner nu uforudsigelig. Som led i et større forskningsprojekt, der søger at finde 'nordiske svar på geopolitiske udfordringer', belyser artiklen den aktuelle udenrigspolitiske debat i Danmark for at afdække, hvilke udenrigspolitiske instrumenter danske politikere lægger særlig vægt på i disse år. Fokus er med andre ord på 'værktøjskassen' og spørgsmålet om, hvorvidt de ansvarlige beslutningstagere er optaget af at finde nye udenrigspolitiske virkemidler, eller om de primært søger at justere brugen af kendte redskaber.

Gennem en analyse af den måde, hvorpå de ansvarlige danske politikere italesætter de aktuelle udenrigspolitiske udfordringer og muligheder, identificerer artiklen den dominerende fortælling om Danmarks fremtidige placering og ageren i en verden, der fra politisk hold opleves som stadig mere usikker og uforudsigelig. Artiklens hovedpåstand er, at denne fortælling rummer en række spændingspunkter - eller selvmodsigelser - der grunder i et voksende skel mellem det, beslutningstagerne opfatter som udenrigspolitisk nødvendigt, og det, de betragter som indenrigspolitisk muligt.

Debatten om Danmarks tilpasning til en verden i hastig forandring udspiller sig således på et indenrigspolitisk bagtæppe, hvor hensynet til en stram udlændingepolitik og ønsket om at udvise økonomisk ansvarlighed overskygger de fleste andre politiske målsætninger. Det kommer til udtryk i en daglig udenrigspolitisk diskurs, der gennem flere år har været præget af ønsker om at "tage kontrollen tilbage" (DR 2018), sikre Danmark "et pusterum" (Berlingske 2017) og undgå "overimplementering" af internationale forpligtelser (Erhvervsministeriet 2015). Det engang så globalt engagerede foregangsland synes i stigende grad at sætte Danmark først. Selv udviklingsbistanden legitimeres $\mathrm{i}$ dag primært som et instrument til at "passe på Danmark" (Regeringen 2017a). Samtidig fastholder det udenrigspolitiske establishment dogmet om, at Danmark som et lille land har en fundamental - og i disse år øget - interesse i at bevare og styrke det forpligtende internationale samarbejde og de multilaterale organisationer, der danner rammen om den regelbaserede globale orden (Regeringen 2017a). Derfor er artiklens konklusion, at det danske svar på de seneste års globale udviklingstendenser indtil videre fremstår usammenhængende og ufuldstændigt og den danske udenrigspolitiske identitet mindre klar end før. 


\section{De lange linjer i nyere dansk udenrigspolitik}

Danmarks udenrigspolitiske selvforståelse forstås bedst med udgangspunkt i daværende udenrigsminister Per Hækkerups doktrin fra 1965, som fastslog, at

isolation og neutralitet ikke byder sikkerhed for Danmark, men at det er nødvendigt at søge sikkerheden hvor den kan opnås, dvs. at basere vores udenrigspolitik og nationale sikkerhed i et udvidet internationalt samarbejde og på sammenholdet $\mathrm{i}$ den demokratiske vestlige verden (Hækkerup 1965: 29).

Tanken har fortsat dogmatisk status. Spørgsmålet, der dengang som nu optager de udenrigspolitisk ansvarlige, er, ikke hvorvidt Danmark skal være internationalt engageret, men hvordan. Efter den kolde krigs afslutning har danske politikere - og forskere - yndet at betegne dansk udenrigspolitik som aktiv, eller ligefrem aktivistisk. I 1990'erne byggede Danmarks såkaldte 'aktive internationalisme' på en bred forankring i de fire multilaterale hjørnestene, Hækkerup i sin tid havde identificeret: Nordisk samarbejde, EF/EU, NATO og FN, og derfor fremstod aktivismen i første omgang ikke som et radikalt brud, men snarere som et udtryk for, at småstatens udenrigspolitiske handlerum var øget (Petersen 2004).

Terrorangrebet på USA den 11 . september 2001 og regeringsskiftet i november samme år indvarslede et brud med den brede konsensus, der indtil da havde præget dansk udenrigspolitik. Under ledelse af Anders Fogh Rasmussen (V) skærpedes den værdipolitiske profil samtidig med, at Danmark i stedet for at fastholde det traditionelle multilaterale udgangspunkt lagde vægt på at "indgå i skiftende alliancer med partnere, vi har interessesammenfald med" (citeret fra Petersen, 2004: 574). Den "aktive internationalisme" blev til "international aktivisme" (Pedersen 2012), og - fordi det danske engagement i omverdenen var så snævert bundet op på amerikansk lederskab - fremstod Danmark som "super-atlantist" (Mouritzen 2007). Især den øgede danske villighed til at bruge militæret som et centralt udenrigspolitisk instrument er omstridt både blandt politikere og forskere (se f.eks. Rynning 2003; Pedersen \& Ringsmose 2017 og Lidegaard 2018). Var det med Irak-krigen 2003, at militariseringen af dansk udenrigspolitik tog fart, eller fandt det afgørende brud sted allerede i 1990'erne med dansk deltagelse i Balkan-krigene? For dette studies formål er spørgsmålet ikke afgørende. Mere interessant er det at konstatere, at 'aktivismen' også indvarslede en forskydning af Danmarks multilaterale forankring væk fra de oprindelige fire hovedhjørnestene over mod to søjler: EU og NATO.

Det er for dette studies formål bemærkelsesværdigt at konstatere ikke bare, hvor lidt dansk aktivisme der har været i forhold til det nordiske samarbejde siden den kolde krigs ophør, men også hvordan denne arena umærkeligt er blevet tillagt stadig mindre vægt over tid (Olesen 2017). Norden betragtes i dag primært som rammen om et lavpraktisk og pragmatisk samarbejde (Bailes 2016). Danske politikere og embedsmænd fremhæver gerne fordelene ved det tætte 'hverdagsdiplomatiske' samarbejde - fælles nordiske ambassader og koordination/erfaringsudveksling om 
især udviklingspolitiske spørgsmål (Marcussen 2017: 198-202) - mens nordisk samarbejde på mere overordnet politisk niveau antager en "lidt pånødet form", eller direkte afvises fra dansk side (Olesen 2017: 370).

På samme måde som det nordiske gled bort fra kernen i dansk udenrigspolitik, er det danske engagement i FN stilnet af (Jakobsen \& Kjærsgaard 2017). FN betragtes ifølge Udenrigsministeriets hjemmeside fortsat som "uerstattelig" pga. organisationens "unikke autoritet og legitimitet", men dansk FN-politik vedligeholdes i stigende grad af embedsværket og uden at påkalde sig større politisk interesse eller debat, hverken i regeringen, på Christiansborg eller i medierne.

Den lidt paradoksale konklusion er, at i takt med at dansk udenrigspolitik op gennem 1990'erne og især efter 2001 fik stadig mere karakter af værdikamp, blev Norden og FN - de to traditionelle fora for varetagelse af Danmarks normative og ideelle interesser - i stigende grad marginaliseret. Tilbage stod EU og NATO som de to væsensforskellige søjler, dansk udenrigspolitik hvilede på. Der er efter den kolde krigs afslutning blevet etableret en bred udenrigspolitisk konsensus i det danske Folketing om, at NATO er garanten for dansk sikkerhed, mens EU er rammen om dansk velfærd. Samtidig gælder det, at mens Danmark aktivt har tilstræbt at være et kerneland i NATO og en loyal allieret for USA, har Danmark pga. EU-forbeholdene effektivt sat sig selv uden for det europæiske samarbejde på en række centrale områder og dermed etableret sig selv som 'fodslæbende' i forhold til det europæiske projekt. Valgene i 2016 - Trump og Brexit - satte med ét spørgsmålstegn ved denne identitet og rystede det danske udenrigspolitiske establishments forståelse af Danmarks forankring i verden.

\section{At passe på Danmark}

Debatten om fremtiden for dansk udenrigspolitik udspiller sig mellem tre positioner: nationalisme, national-liberalisme og kosmopolitisme (Rasmussen 2017). Nationalisterne er optaget af at forsvare det danske folk mod islam og politisk korrekt 'globalisme'. De nationalliberale ønsker at fastholde Danmarks internationale engagement $i$ en globaliseret verden, men er optaget af at sikre, at Danmark får mest muligt ud af sine relationer med omverdenen. Kosmopolitterne bekymrer sig om klodens tilstand, menneskehedens overlevelse og behovet for større solidaritet på tværs af landegrænser. Det udenrigspolitiske establishment i Danmark består altovervejende af nationalliberalister, der søger at imødekomme nationalisterne så langt som muligt især på udlændingeområdet - for ikke at fremstå som en del af en verdensfjern elite. Kosmopolitternes stemme er dermed den mest trængte i den aktuelle danske debat.

For at forstå den konstellation er det nødvendigt at starte i Socialdemokratiet. Den ophedede kamp om forskellige udenrigspolitiske visioner, der udspillede sig i starten af 00'erne, blev lagt på hylden op gennem 10'erne i takt med, at Socialdemokratiet på afgørende punkter flyttede sig. Socialdemokratiet har således siden 2011 
haft som erklæret politik, at Danmark kan deltage i militære operationer også uden FN-mandat, og i 2017 forlod partiet også sin ellers meget lange og faste målsætning om at ville bruge 1\% af BNP på udviklingsbistand. Samtidig har Socialdemokratiet nærmet sig Dansk Folkeparti på udlændingepolitikken og har siden migrationskrisen i 2015 betragtet området som det centrale omdrejningspunkt i både europæisk og dansk politik.

Udviklingen afspejler, at ledende danske politikere i både regering og opposition i dag betragter dét at have en stram udlændingepolitik som en nødvendig, men ikke tilstrækkelig forudsætning for at bevare eller genvinde regeringsmagten.Vil man være helt sikker på at fange tidsånden, må man også gå til kanten af eller udfordre internationale konventioner og forpligtelser - især på udlændingeområdet. Denne udvikling har været undervejs længe, men migrationskrisen i 2015 førte på mange måder til en radikalisering af debatten ikke bare i Danmark men i hele Europa.

Udover en række markante stramninger i dansk udlændingepolitik, herunder et stop for modtagelse af kvoteflygtninge, førte migrationskrisen til et kraftig øget fokus på tilbagetagelse, dvs. muligheden for at kunne sende ikke-ønskede udlændige tilbage til deres hjemlande. Dette ses mest tydeligt i udviklingspolitikken, der nu eksplicit bruges som stok og gulerod for at få tilbagetagelsesaftaler på plads med lande som Somalia, Etiopien, Afghanistan, Marokko og Kenya, og i udnævnelsen af en særlig 'udsendelsesambassadør' med ansvar for at sikre netop dette (Udenrigsministeriet 2017a: 23-24). Hensynet til tilbagetagelse prægede også den danske position i FN-forhandlingerne om omfattende 'compacts' på både migrations- og flygtningeområdet (Udenrigsministeriet 2017b: 10), ligesom det har ført til et dansk opgør med den Europæiske Menneskerettighedsdomstols såkaldte dynamiske fortolkningspraksis: "Der er behov for en ny rimelighed. De europæiske samarbejder både i EU og i Europarådet - skal give mening for borgeren", forklarede statsministeren i sin tale ved Folketingets åbning 3. oktober 2017 og pegede bl.a. på det i hans øjne uforklarlige og urimelige i, at Danmark ikke kan udvise dybt kriminelle udlændinge ud fra hensyn til disses familie- og privatliv (Statsministeriet 2017b).

Sagen er et eksempel på en dagsorden, der set med danske indenrigspolitiske briller giver mening, men som vækker undren og kritik, når regeringen forsøger at føre den ud i livet i de relevante internationale sammenhænge (Politiken 2018a, b). Det er også af den grund vanskeligt at se bort fra udlændingepolitikkens betydning for aktuel dansk udenrigspolitik. Samtidig gælder det dog som nævnt, at andre mere klassiske, udenrigspolitiske spørgsmål, der dybest set handler om Danmarks fremtidige placering i verden, siden 2016 har optaget de ansvarlige beslutningstagere. Opfattelsen af at stå midt i en 'brydningstid' præger debatten og viser sig blandt andet $i$ et øget fokus på spørgsmålet om Danmarks forhold til 'de fire store' magtcentre: USA, EU, Rusland og Kina. I det følgende gennemgås disse for at afdække, på hvilken måde de hver især fremstilles som hhv. udfordringer og muligheder, der fordrer udenrigspolitisk nytænkning. 
Trump og det nye USA

Selvom regeringen i sin udenrigspolitiske strategi fra 2017 omhyggeligt undlod at forholde sig til det, udenrigsministeren kalder "Trump og hans særlige stil" (Samuelsen 2018), står det i stigende grad klart, at det markant anderledes USA, der viser sig under Trumps ledelse, vækker stor bekymring i Danmark. I lighed med Norge, lagde Danmark sig meget tidligt fast på en linje, der fastholder USA som Danmarks vigtigste allierede - især på det sikkerhedspolitiske felt. Et bredt flertal i Folketinget - Kun Socialistisk Folkeparti, Alternativet og Enhedslisten stod udenfor - blev i januar 2018 enige om et nyt forsvarsforlig for perioden 2018-2023, der fastslår, at "NATO er og bliver hjørnestenen i dansk forsvars- og sikkerhedspolitik" (Forligskredsen 2018). Forliget indebar et såkaldt 'substantielt løft' af det danske forsvarsbudget med mere end $20 \%$ - med henvisning til Rusland og den forværrede sikkerhedssituation i Danmarks nærområde, herunder nye trusler fra cyber og påvirkningskampagner. Det var magtpåliggende for regeringen og det brede udsnit af de danske partier, der stemte for forsvarsforliget, at stigningen i det danske forsvarsbudget ikke sås som en særlig imødekommelse af Trump, men derimod som en indfrielse af et løfte givet til Obama. Den politiske vilje til at finde flere penge til det danske forsvar steg dog bemærkelsesværdigt, efter at Trump var kommet til magten i USA og havde sat spørgsmålstegn ved USA's forpligtelse over for NATO (Mouritzen forthcoming).

På andre områder har regeringen åbent erkendt, at Danmark ikke kan læne sig op ad eller forvente amerikansk lederskab under Trump. Danmark var i marts 2017 medinitiativtager til "SheDecides" som udviklingspolitisk modspil til genindførelsen af den såkaldte Global Gag Rule. Trumps politik er ifølge udviklingsminister Ulla Tørnæs "til at blive harm og desperat over" (Berlingske 2018). Mindst lige så bekymrende opfattes Trumps politik i forhold til klima og frihandel. Især den gryende handelskrig mellem USA og EU fremstår voldsomt foruroligende for en lille åben økonomi som den danske. Som modtræk angives det i regeringens ny strategi for økonomisk diplomati, at Danmark - gennem EU og WTO - fortsat vil føre en "aktiv, liberal og ambitiøs handelspolitik" og stå vagt om de fælles "færdselsregler", der sikrer frihandel (Regeringen 2018: 9). Danmark forsøger samtidigt at arbejde med et langt bredere felt af partnere i USA, på delstatsniveau og i Kongressen, for generelt at fastholde amerikansk engagement $i$ det internationale samarbejde. I forbindelse med FN's Generalforsamling 2017 lancerede statsminister Lars Løkke Rasmussen således en særlig klima- og verdensmålsfond - Partnering for Green Growth and Global Goals (P4G) - der skal understøtte grønne initiativer i de byer og lande, der tilslutter sig den (Statsministeriet 2017a). Sigende for disse tiltag er, at de udover at være en reaktion på Trumps America First politik - er bundet tæt op på det, regeringen selv kalder "danske kommercielle styrkepositioner" (Regeringen 2017a).

\section{Brexit og frygten for marginalisering i Europa}

Det andet store problem, der optager det udenrigspolitiske establishment, er EU's fremtid og Danmarks relation til EU efter Brexit (Sørensen \& Wivel 2017). I den 
første tid efter den britiske folkeafstemning var der fra dansk side mest fokus på at sikre, at danske erhvervsinteresser blev tilgodeset bedst muligt i forhandlingerne mellem Storbritannien og EU27. Gradvist er dette fokus blevet suppleret af en mere langsigtet bekymring for, om Danmark ryger yderligere ud i periferien af $\mathrm{EU}$, når den EU-skeptiske storebror forlader samarbejdet.

Statsministeren føler sig overbevist om, at EU's betydning for Danmark kun er vokset siden Trump og Brexit: "Europa er fremtiden. EU er fremtiden for Danmark, det er uomtvisteligt" (Altinget 2018). Han ser på den baggrund gerne en fornyet debat om forbeholdene, men har ingen planer om selv at foreslå dem afskaffet - heller ikke selvom de i stigende grad opfattes som en utidssvarende spændetrøje, der fastholder Danmark i periferien af det samarbejde, regeringen ser som "vores bedste mulighed for at påvirke verden omkring os" (Regeringen 2017a). I Folketinget er det kun - og kun i begrænset omfang - det Radikale Venstre, der udfordrer regeringen på dette spørgsmål og advokerer for en snarlig afskaffelse af forbeholdene, mens de øvrige partier forholder sig enten afventende eller mere åbenlyst EU-skeptiske. Senest har Socialdemokratiet helt opgivet sin principielle modstand mod forbeholdene og angivet, at de ser dem som grundlaget for dansk Europa-politik. Socialdemokratiets formand, Mette Frederiksen, mener, at Danmark "sagtens [kan] være medlem af EU med forbeholdene uden problemer. Hele dette ønske hos nogle ambassadører og nogle af EU-landene om stadig mere integration for integrationens skyld deler jeg ikke" (DR 2018).

Selvom statsministeren har anslået en lidt mere EU-positiv retorik, deler regeringen grundlæggende det synspunkt: Statsministeren ønsker - med direkte henvisning til Sverige, Finland, Holland, Østrig og måske Irland og lidt mere skjult reference til den franske præsident Macron - at styrke og udbygge samarbejdet med de EU-lande, der - ligesom Danmark - er "mere pragmatiske, nordeuropæiske og regelrette og mindre floromvundne" (Altinget 2018). Samtidig er det dog vurderingen, at Danmark for ikke helt at glide ud i periferien især må og skal styrke sit forhold til Tyskland. Tyskland betragtes i stigende grad som nøglen til dansk indflydelse i verden - både i og udenfor EU. Fra at have været betragtet som en potentiel trussel, der skulle indbindes i internationalt samarbejde, fremstår Tyskland, ikke mindst qua sin rolle i eurozonen, i stigende grad som garanten for Danmarks velfærd og velstand. Spørger man i Udenrigsministeriet, hvilket land der betyder mest for Danmark i dag, er svaret utvetydigt.

Forholdet til Rusland

Det tredje store udenrigspolitiske spørgsmål, der optager sindene, er forholdet til Rusland. Debatten er præget af en vis dobbelthed - og nok også af en vis intern uenighed i regeringen om, hvordan truslen fra Rusland bedst imødegås. Regeringens udenrigs- og sikkerhedspolitiske strategi understreger, at Danmark er "bekymret over Ruslands selvhævdende adfærd i nærområdet, men Rusland er også en nabo, som Danmark skal opretholde forbindelser til" (Regeringen 2017a). I praksis betyder det, 
at Danmark taler med store bogstaver til Rusland gennem EU og NATO, mens man i bilaterale relationer og i Arktis søger dialog. Fra dansk side lægger man vægt på at modvirke russisk isolation, men viljen til dialog afspejler også et ønske om at undgå at tiltrække sig særlig russisk vrede vendt mod Danmark. Denne dobbelthed gør det - i lighed med de øvrige nordiske lande - vanskeligt at placere Danmark som enten 'høg' eller 'due' i forholdet til Rusland (Mellander og Mouritzen 2016).

Småstaten Danmarks klemte position mellem stormagterne - og mellem sit europæiske og transatlantiske engagement - ses tydeligt i den verserende sag om Nord Stream 2. Rusland har anmodet Danmark om lov til at føre en ny gasledning til Tyskland gennem dansk søterritorium i Østersøen. Tyskland betragter ledningen som et spørgsmål om energiforsyning og ønsker, at Danmark svarer ja, mens USA ser på ledningen med sikkerhedspolitiske briller og ønsker, at Danmark skal svare nej. For at komme ud af denne knibe har Danmark søgt at skubbe problemet videre til EU og få Kommissionen til at forhandle linjeføringen på plads med Rusland, men uden held, og Danmark må derfor fortsat kæmpe videre med sig selv om svaret. Den samlede opposition har opfordret regeringen til at afvise det russiske ønske. Regeringen forholder sig dog stadig afventende og har angiveligt større lydhørhed over for ekspertargumenter om, at et nej ikke kun vil påvirke forholdet til Rusland negativt, men også skade relationen til Tyskland, uden reelt at opnå andet end forsinkende omlægning af linjeføringen uden om dansk søterritorium (Mouritzen 2018).

Mulighedernes land: Kina

I en tid præget af krise og usikkerhed er det magtpåliggende for regeringen at understrege, at de globale forskydninger også skaber nye muligheder. Det gælder ikke mindst i forhold til vækstøkonomierne, herunder især Kina. Udenrigsministeriets egen globaliseringsanalyse fra 2006 lagde allerede dengang op til en omprioritering af ressourcer fra Europa til Asien, med særlig fokus på Kina og Indien (Udenrigsministeriet 2006: 16). Ti år senere, men før Brexit og Trump, lagde den såkaldte Taksøe-udredning op til at forstærke tendensen yderligere ved at plædere for - eller konsolidere - en særlig asiatisk dimension som supplement til Danmarks europæiske og transatlantiske forankring (Taksøe-Jensen 2016).

Danmark har i de seneste år styrket sin relation til Kina betydeligt, og Kina er hastigt på vej til at blive Danmarks største handelspartner uden for EU. Dette er sket især gennem det såkaldte Comprehensive Strategic Partnership, der blev indgået i 2008, og som danske embedsmænd og politikere ikke uden stolthed fremhæver som noget, ingen af de andre nordiske lande har. Sideløbende med, at det bilaterale forhold til Kina er styrket - symboliseret gennem Kinas udlån af to pandaer til Københavns ZOO - er den danske kritik af menneskerettighedssituationen i Kina kørt over i en multilateral/EU-ramme. Ræsonnementet er, at man som et lille land kommer længst med det stille diplomati og ved at undgå en moraliserende tone over for stormagterne (Forsby 2016). I lyset heraf fremstilles Kina fra officielt hold stort set kun som en mulighed for Danmark - om end der i stigende grad, blandt andet fra regeringens 
støtteparti, Dansk Folkeparti, er øget opmærksomhed på Kina som en voksende trussel mod de liberale værdier og den amerikansk-ledede verdensorden.

\section{At fokusere og prioritere}

Som det fremgår, er debatten i Danmark præget af en grundlæggende forestilling om, at den omkringliggende verden bliver stadigt mere uforudsigelig og usikker. Reaktionerne på især Trump, Brexit og Rusland afspejler en grundlæggende dansk bekymring for den kommende verdens(u)orden. Ifølge udenrigsministeren skal netop det "at værne om det internationale samarbejde for på den måde at varetage Danmarks interesser bedst muligt", være udgangspunktet for de kommende års danske udenrigspolitik. Indtil videre er der dog endnu ikke fra dansk side gjort forsøg på at formulere en eksplicit ordenspolitik eller en sammenhængende analyse af, hvor og hvordan Danmark skal sætte ind med et styrket dansk forsvar for den regelbaserede orden og det multilaterale samarbejde, der jf. Hækkerup-doktrinen er dér, hvor dansk sikkerhed skal søges.

De udfordringer, der skal håndteres gennem dansk udenrigspolitik, er allerede store, og de må forventes at vokse voldsomt i de kommende år. Denne opfattelse er bredt accepteret i regeringen og Folketinget. Erkendelsen har dog (endnu) ikke fået politikerne til at afsætte flere penge til Danmarks internationale engagement. Forsvaret fik i januar 2018 som nævnt tilført yderligere midler, men der er ikke udsigt til, at hverken diplomatiet eller udviklingsbistanden vil blive styrket tilsvarende i de kommende år. Tværtimod synes der at være bred enighed om, at niveauet for Danmarks civile engagement i omverdenen er passende, og at opgaven derfor består i dels at stramme op - at fokusere, prioritere og koncentrere sig om det, der virkelig betyder noget - dels at organisere arbejdet anderledes - mere dynamisk, fleksibelt og digitalt. Sideløbende med den politiske debat om Danmarks fremtidige placering i verden, har Udenrigsministeriet derfor i de seneste år søgt at formulere rammerne for "Fremtidens udenrigstjeneste" $i$ en tid, hvor "ressourcerne er skåret ind til benet" (Udenrigsministeriet 2018b; Innovationsgruppe 2 2016; se også Marcussen 2016).

At den danske udenrigstjeneste føler sig presset, er ikke nyt. I takt med, at globaliseringen har udvisket skellet mellem indenrigs- og udenrigspolitik, er diplomatiets monopol på det internationale samarbejde brudt, og tyngdepunktet i beslutningsprocessen flyttet fra Udenrigsministeriet til Statsministeriet. Denne tendens ses i de fleste EU-lande og afspejler en forskydning af udenrigspolitikken 'opad' til stats- og regeringschefniveau og 'udad' til andre fagministerier med ansvar for f.eks. miljø-, energi-, og udlændingepolitik (Pilegaard 2013). Samtidig er udenrigspolitikken på godt og ondt demokratiseret. Udenrigspolitik opfattes ikke længere som et særlig ophøjet felt og må derfor i stigende grad kæmpe om ressourcer og opmærksomhed på lige fod med andre og mere borgernære emner. Fra 2000 til 2016 blev Udenrigsministeriets driftsbevilling beskåret med ca. en tredjedel (i alt 600 mio. kr.), og den danske udenrigstjeneste er med 95 repræsentationer i dag den mindste i Norden (Island 
undtaget) (Taksøe-Jensen 2016) ${ }^{1}$. I dag beskæftiger Udenrigsministeriet i alt 2648 mennesker. Heraf arbejder de 817 'hjemme' på Asiatisk Plads i København, mens de øvrige 1.759 arbejder 'ude' på de danske repræsentationer. Langt hovedparten af disse er dog lokalt ansatte (1.140), og det samlede antal udsendte medarbejdere i den danske udenrigstjeneste er således kun 349 (Udenrigsministeriet 2018c).

De politisk set vigtigste danske repræsentationer i udlandet er: EU-repræsentationen i Bruxelles, Beijing, Washington, Paris, FN-missionen i New York, Moskva, Berlin og London. Ambassadørposten på disse syv repræsentationer besættes i regeringens ansættelsesudvalg, mens Udenrigsministeriets ledelse selv fordeler de øvrige ambassadørposter. Målt i antal udsendte medarbejdere er EU-repræsentationen Danmarks ubetinget største repræsentation. EU-rep'en ligger med over 50 udsendte langt over alle andre. Ambassaden Beijing er nu den næststørste danske repræsentation og den eneste af de syv 'prestigeposter', der i dag (2017) har flere udsendte medarbejdere (19) end i 2001 (9). I samme periode er Washington gået fra 24 til 17, FN-missionen fra 25 til $12 \mathrm{og}$ - måske mest overraskende set i lyset af den vægt Tyskland tillægges fra politisk side - Berlin fra 22 til 8 udsendte medarbejdere.

En del af faldet hænger sammen med den reduktion af den danske udviklingsbistand, der blev indledt af VK-regeringen i 2001 og siden videreført af skiftende regeringer. Ifølge den seneste opgørelse fra OECD udgjorde Danmarks udviklingsbistand i 20160,75 procent af bruttonationalindkomsten, hvilket er det laveste niveau siden 1983. Det er regeringens erklærede mål at sænke bistandsprocenten yderligere for at nå ned på FN's 0,7 procent målsætning.

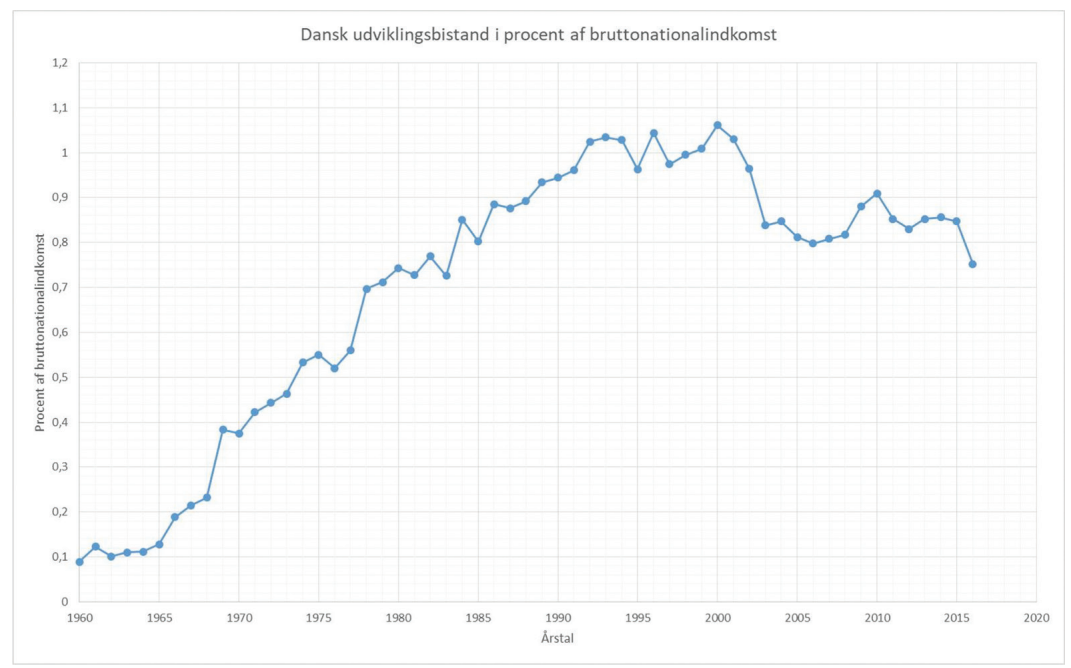

Figur 3. Dansk udviklingsbistand i procent af BNI, 1960-2016

Kilde: $O E C D$

\footnotetext{
${ }^{1}$ Besparelserne blev bremset i 2017, hvor Udenrigsministeriets budget blev øget med 70 mio. kr. årligt. Dette beløb modsvares dog delvist af det såkaldte 'omprioriteringsbidrag', som alle ministerier skal indbetale til Finansministeriet på $2 \%$ af deres samlede budget. For Udenrigsministeriets vedkommende udgør det ca. 30-32 mio. kr.
} 
Indtrykket af en bevidst dansk nedprioritering af det udenrigspolitiske område forstærkes af den ganske omfattende skare af ministre, der de seneste ti år har haft deres gang i Udenrigsministeriet som enten udenrigsminister (7), udviklingsminister (6), minister for nordisk samarbejde (8) og/eller handelsminister (3). Der er stadig forbundet med prestige at være udenrigsminister i Danmark, men hensynet til at sikre kontinuitet på posten og dermed international gennemslagskraft har ikke fyldt meget, når skiftende statsministre $i$ de seneste ti år har sammensat deres ministerhold. De mange ministre afspejler også, at det danske udenrigsministerium udover udenrigsog sikkerhedspolitik også varetager europapolitik, udviklingspolitik, handelspolitik, erhvervs- og investeringsfremme samt borgerservice. Udenrigsministeriet ser selv dette som en styrke, der "gør det muligt at levere konkrete svar på internationale og globale udfordringer på tværs af arbejdsområder uden organisatoriske og forvaltningsmæssige hindringer" (Udenrigsministeriet 2018c).

Netop denne evne til at 'samtænke' forskellige politikområder, herunder især udvikling og sikkerhed, opfattes generelt som et af Danmarks stærkeste kort i forhold til at håndtere komplekse problemer i en stadig mere usikker verden. Danske beslutningstagere fremstiller gerne Danmark som et land, der "leverer, hvor andre taler", og som har indflydelse, "fordi vi peger på brugbare løsninger og søger løsninger, hvor andre søger konflikt" (Jensen 2016). I kandidaturet til FN's Menneskerettighedsråd 2019-2021 fremhæver regeringen Danmarks "respekterede rolle som skaber af konstruktiv dialog" og lover at "arbejde for at bygge broer og indgå kompromiser blandt Rådets medlemmer" (Udenrigsministeriet 2018d).

Formuleringerne er karakteristiske for den danske selvopfattelse og ønsket om at fremstå som en fornuftens stemme i internationale sammenhænge. Måske derfor kommer det ofte bag på det officielle Danmark, når danske initiativer og politikker giver anledning til kritik i udlandet. Kritikken opfattes som uberettiget og/eller baseret på misforståelser, der skal udryddes ved hjælp af public diplomacy. Udenrigsministeriet har siden Tegningesagen i 2006 måttet bruge stadigt flere ressourcer på at forsøge at bryde "mediespiraler, der sætter negativ fokus på historier om Danmark og giver ridser i Danmarks omdømme" (Taksøe-Jensen 2016: 45). Måske har andre lande vanskeligere ved at genkende Danmarks internationale profil nu end for 10-15 siden?

Det danske 'brand' opfattes dog generelt som stærkt, og Danmark ynder at se sig selv som et land, der 'bokser over sin vægtklasse'. Forhenværende udenrigsminister Kristian Jensen har peget på fire særlige danske "trumfkort", der sikrer Danmark indflydelse og adgang ude i verden: Udviklingsbistandens omfang og kvalitet, erhvervsmæssige styrker indenfor clean-tech, medicin og fødevarer, viljen til at stille militære styrker til rådighed i internationale operationer samt Rigsfællesskabet og den arktiske rolle i kraft af Grønland (Jensen 2016: 213). Til denne liste kan føjes 'den danske samfundsmodel' som en samlebetegnelse for Danmarks erfaringer med f.eks. grøn omstilling, fleksibelt arbejdsmarked og forskellige velfærdsløsninger. Myndighedssamarbejde og udsendelse af såkaldte 'vækstrådgivere' fra relevante fagministerier betragtes i stigende grad som en effektiv vej til at sikre Danmark indflydelse ude og jobs hjemme. 
En anden udenrigspolitisk nyskabelse, der synes at være kommet for at blive, er brugen af tematiske ambassadører. Udnævnelsen i 2017 af en såkaldt 'Tech-ambassadør' med "globalt mandat til at fremme teknologidagsordenen internationalt" fremhæves af Udenrigsministeriet som særligt fremsynet og visionær. Tech-ambassadøren har base i Silicon Valley og adskiller sig dermed fra de øvrige tematiske ambassadører, der typisk arbejder fra København. Det gælder således både den tidligere nævnte 'udsendelsesambassadør' og den 'særlige repræsentant for religions- og trosfrihed', der blev udnævnt i efteråret 2017 for at styrke det internationale samarbejde for at beskytte religiøse mindretal i Danmarks nærområder, herunder især kristne. Blandt andre emner, der tidligere har ført til udnævnelsen af særlige ambassadører, kan nævnes Arktis, Det arabiske initiativ, Skrøbelige stater og Sahel/Magreb. Selvom de enkelte udnævnelser har haft hver sin konkrete begrundelse, afspejler de som hovedregel et ønske om - med begrænsede midler - at vise handlekraft inden for et politisk højprioriteret område.

\section{Konkluderende bemærkninger}

I betragtning af den omfattende krisestemning, der kendetegner debatten, fremstår dansk udenrigspolitik i bemærkelsesværdig grad præget af kontinuitet og konsensus. Regeringen og dens embedsmænd taler ganske vist om 'tektoniske plader i bevægelse', og om 'fundamentalt ændrede rammebetingelser', men helt overordnet holder regeringen og et bredt flertal i Folketinget fortsat fast i, at EU og NATO udgør de to altoverskyggende, men væsensforskellige, hjørnestene i dansk udenrigspolitik: NATO-medlemskabet (og dermed USA) er fortsat garanten for Danmarks sikkerhed, mens EU udgør fundamentet for Danmarks velstand. Hverken FN eller Norden - de to andre 'gamle' hovedhjørnestene i dansk udenrigspolitik - har således oplevet en særlig politisk renæssance i Danmark som et globalt og/eller regionalt alternativ til de kriseramte europæiske og transatlantiske samarbejdsfora. Tværtimod tegner der sig en bred og stigende opbakning - også i den danske befolkning - til at fastholde Danmark i både EU og NATO-samarbejdet.

Samtidig har Danmark i de seneste år udvidet sin udenrigspolitiske værktøjskasse med en række nye tiltag og instrumenter, der skal sikre, at danske interesser - især de kommercielle - kan varetages på nye måder i en foranderlig verden. Tech-ambassadøren, myndighedssamarbejde og den nye klima- og verdensmålsfond er markante eksempler. Fælles for disse instrumenter er, at de - i lighed med den massive fokusering på migration og udlændinge - handler om 'issues' fremfor institutioner. De gør det muligt at markere Danmark på et givet område i en kortere periode, men bidrager kun indirekte til at svare på de grundlæggende spørgsmål om dels den fremtidige balance mellem Danmarks nordiske, europæiske, transatlantiske og globale engagement, dels samspillet mellem Danmarks værdimæssige, sikkerhedspolitiske og økonomiske interesser.

På sin vis kan den politiske fokus på de nye instrumenter derfor ses som udtryk for et opgør med det høje ambitionsniveau, der ellers har præget dansk udenrigspolitik 
siden den kolde krigs afslutning. Gennem de seneste år har hverken retorikken eller ressourcerne understøttet et særskilt dansk ønske om 'at gøre en forskel' og søge at påvirke den globale udvikling. Tværtimod har der været stigende fokus på at 'passe på Danmark' og sikre, at danske interesser bliver varetaget bedst muligt, mens verden går sin skæve gang. De seneste udmeldinger fra regeringen fastholder dette fokus, men antyder, at udfordringen - især efter Brexit og Trump - ikke består i at afvikle dansk aktivisme til fordel for en passiv dansk tilpasningspolitik. Opgaven består i at nytænke Danmarks aktive internationale engagement, så Danmark - også i en brydningstid - kan varetage sine fundamentale interesser $i$ at bevare og styrke den regelbaserede internationale orden og det udvidede internationale samarbejde, der jf. Hækkerup-doktrinen opfattes som det eneste sted, hvor Danmark kan søge sikkerhed. Udenrigsministeren angiver således, at han "er bange for, at der er flere danskere derude - også på Christiansborg - der ikke er helt klar over, hvad der er på spil: Vi kan ganske enkelt ikke varetage vores interesser i verden på egen hånd" (Samuelsen 2018). Statsministerens forsøg på at sparke en positiv debat i gang om Danmarks forhold til EU peger i samme retning, men understreger samtidig, at regeringen på dette område ikke har tænkt sig at løbe hurtigere på det udenrigspolitiske område end dens parlamentariske bagland tillader. Regeringen lægger først og fremmest op til en ændring af retorikken: "Lad os i stedet tale både Danmark og Europa op. Stå ved det kontinent og samarbejde, vi er en del af. Og diskutere Europa - uden en folkeafstemning i horisonten. Det, tror jeg, vil være godt”, som statsministeren sagde i sin afslutningstale i Folketinget den 28. maj 2018 (Statsministeriet 2017b).

De globale omvæltninger - især Trump og Brexit - har angiveligt sat gang i en erkendelsespolitisk proces, der skubber dansk udenrigspolitik i retning af et styrket dansk EU-engagement og et forsøg på at fastholde den transatlantiske alliance samtidig med, at den liberale orden - især frihandlen - skal forsvares, samhandlen med vækstøkonomierne styrkes, og sikkerheden i nærområdet øges. På alle måder en massiv dagsorden, der kalder på en generel opprioritering af udenrigspolitikken og et øget dansk engagement $i$ alle centrale internationale samarbejdsinstitutioner. I praksis - f.eks. når pengene skal findes på finansloven - er det, dog indtil videre svært at se et sådant kursskifte materialisere sig. I stedet fremstår dansk udenrigspolitik i stigende grad usammenhængende, fordi skellet mellem det, der vurderes at være udenrigspolitisk nødvendigt, og det, der vurderes at være indenrigspolitisk muligt, vokser.

\section{Om forfatteren}

Louise Riis Andersen er seniorforsker ved Dansk Institut for Internationale Studier.

\section{Om artiklen}

Jeg skylder mange mennesker tak for hjælp med denne artikel. Det gælder udover de centralt placerede embedsmænd, der har taget sig tid til at tale med mig om 


\section{baggrunden for regeringens tiltag og initiativer, også Bo Lidegaard, Hans Mourit-} zen, Lars Vissing og Martin Marcussen, der har læst og kommenteret udkast undervejs. Kristin Haugevik og Ole Jacob Sending, der har stået bag dette fællesnordiske projekt, skal også have særlig tak for deres gode ledelse af projektet - og for at invitere mig med i gruppen.

\section{Referencer}

Altinget (2018) 'Lars Løkke om EU uden briterne: 'Man vil gerne lytte til Danmark ... men der er en risiko for, at vi glider ud i periferien"”, 23.02.2018.

Bailes, Alyson J. K. (2016) “Denmark in Nordic Cooperation: Leader, Player, Sceptic?” i Nanna Hvidt og Hans Mouritzen (red) Danish Foreign Policy Yearbook 2016. København: Dansk Institut for Internationale Studier.

Berlingske (2017) "Støjberg stopper kvoteflygtninge: Vi behøver pusterum", 28.11.2017. https://www.b.dk/ politiko/stoejberg-stopper-kvoteflygtninge-vi-behoever-pusterum.

Berlingske (2018) "Engang havde jeg store forestillinger om fremtiden. Men alle drømme dør, når man får børn", 14.03.2018. https://www.b.dk/nationalt/engang-havde-jeg-store-forestillinger-om-fremtiden.-men-alledroemme-doer-naar

Danmarks Radio (2018) "Socialdemokratiet klar med første store valgoplæg: Slut med at søge asyl i Danmark", 04.02.2018. https://www.dr.dk/nyheder/politik/socialdemokratiet-klar-med-foerste-store-valgoplaeg-slutmed-soege-asyl-i-danmark.

Erhvervsministeriet (2015) "Fem principper skal sikre ny EU-regulering ikke overimplementeres", Pressemeddelelse, 20.11.2015.

Forligskredsen (2018) Aftale på forsvarsområdet 2018-2023, 28.01.2018 http://www.fmn.dk/temaer/ forsvarsforlig/Documents/Forsvarsforlig-2018-2023.pdf

Forsby, Andreas Bøje (2016) ” Norden og Kina: Førsteviolinist i det nordiske ensemble? Danmarks forhold til Kina”, Internasjonal Politikk, 74 (3): 1-9.

Hækkerup, Per (1965) Danmarks udenrigspolitik. Århus: Fremad.

Innovationsgruppe 2 (2016) PIXI Anbefalinger til Fremtidens Udenrigstjeneste. Powerpoint præsentation til Udenrigsministeriet, december 2016.

Jakobsen, PeterViggo \& Kjærsgaard, Kristine (2017) "Den danske FN-aktivismes storhed og fald 1945-2016", Politica, 49 (2): 377-400.

Jensen, Kristian (2016) I Danmarks tjeneste. København: People’s Press.

Marcussen, Martin (2016) Diplomati. Et portrcet af den moderne udenrigstjeneste. København: Hans Reitzels Forlag.

Marcussen, Martin (2017) Diplomati fra bar bund. Hverdagens diplomati på de danske ambassader. København: Djøf Forlag.

Lidegaard, Bo (2018) Danmark $i$ krig. Århus: Aarhus Universitetsforlag.

Mellander, Maria og Hans Mouritzen (2016) "Learning to assert themselves: Small states in asymmetrical dyads - two Scandinavian dogs barking at the Russian bear", Cooperation and Conflict, 51 (4): 447-466.

Mouritzen, Hans (2007) "Denmark's super Atlanticism", fournal of Transatlantic Studies, 5:2, $155-167$.

Mouritzen, Hans (2018) "Forsker: Nej til russisk gasledning er at skyde os selv i foden", Altinget, 08.03.2018.

Mouritzen, Hans (forthcoming) Nordic Russia Policies after Trump. København: Dansk Institut for Internationale Studier.

Olesen, Mikkel Runge (2017) "Aktivismen med de nordiske 'brødre': forsigtig spiren efter lang tids tørke?”, Politica, 49 (2): 358-376.

Pedersen, Rasmus Bruun (2012) "Fra aktiv internationalism til international aktivisme: Udvikling og tendenser i dansk udenrigspolitisk aktivisme”, Politica, 44 (1): 111-130.

Pedersen, Rasmus Brun \& Ringsmose, Jens (2017) ”Aktivisme i dansk udenrigspolitik: Norden, FN, NATO og EU”, Politica, 49 (2): 339-357.

Petersen, Nikolaj (2004) Dansk udenrigspolitisk historie, bind 6: Europceisk og globalt engagement, $1973-2003$. København: Gyldendal.

Pilegaard, Jess (2013) "Udenrigspolitikken er død - længe leve diplomatiet”, Økonomi og Politik, 86: 19-33.

Politiken (2018a) "Regeringen nedtoner opgør med menneskerettighedssystem”, 06.02.2018. https://politiken. $\mathrm{dk} /$ indland/politik/art6327803/Regeringen-nedtoner-opg\%C3\%B8r-med-menneskerettighedssystem 


\section{Louise Riis Andersen}

Politiken (2018b) "Hård udenlandsk kritik af Danmarks udkast til en Københavner-erklæring” 26.02.2018. https:/politiken.dk/udland/int_europa/art6355468/H\%C3\%A5rd-udenlandsk-kritik-af-Danmarksudkast-til-en-\%E2\%80\%99K\%C3\%B8benhavn-erk1\%C3\%A6ring\%E2\%80\%99

Rasmussen, Mikkel Vedby (2017) "Nationalists, National Liberals and Cosmopolitans: Danish Foreign Policy Debates after Brexit and Trump” i Kristian Fischer \& Hans Mouritzen Danish Foreign Policy Yearbook 2017. København: Dansk Institut for Internationale Studier.

Regeringen (2017a) Udenrigs- og Sikkerhedspolitisk Strategi 2017-18. København: Udenrigsministeriet.

Regeringen (2017b) Et stcerkt vcern om Danmark. Udspil til nyt forsvarsforlig 2018-2023. København: Forsvarsministeriet.

Regeringen (2018) Regeringens strategi for økonomisk diplomati. Adgang til verden-nye veje til vekst. København: Udenrigsministeriet.

Rynning, Steen (2003) “Denmark as a strategic actor? Danish Security Policy after 11 September" i Per Carlsen \& Hans Mouritzen Danish Foreign Policy Yearbook 2003. København: Danish Institute for International Studies.

Samuelsen, Anders (2018) Udenrigsministerens tale til Det Udenrigspolitiske Selskab, 05.02.2018 http:// udenrigs.dk/udenrigsministerens-tale-udenrigspolitiske-selskab-5-februar-2018/

Statsministeriet (2017a) "Statsministeren lancerer nyt globalt initiativ for at fremme FN's verdensmål", Pressemeddelelse. 20.09.2017.

Statsministeriet (2017b) Statsminister Lars Løkke Rasmussens tale ved Folketingets åbning den 3. oktober 2017. http://www.stm.dk/_p_14594.html

Sørensen, Catharina \& Wivel, Anders (2017) "Danmark efter Brexit: Business as usual eller en ny begyndelse for dansk Europapolitik?", Internasjonal Politikk, 75 (2): 117-130.

Taksøe-Jensen, Peter (2016) Dansk diplomati og forsvar $i$ en brydningstid. Vejen frem for Danmarks interesser og vcerdier mod 2030. København: Udenrigsministeriet.

Udenrigsministeriet (2006) Den grenseløse verden - Udenrigsministeriet og globaliseringen. København: Udenrigsministeriet.

Udenrigsministeriet (2017a) Verden 2030. Danmarks udviklingspolitiske og humanitcere strategi. København: Udenrigsministeriet.

Udenrigsministeriet (2017b) FN's 72. Generalforsamling. Danmarks prioriteter. København: Udenrigsministeriet.

Udenrigsministeriet (2018b) "Fremtidens udenrigstjeneste" http://um.dk/da/Udenrigspolitik/aktuelle-emner/ fremtidens-udenrigstjeneste/

Udenrigsministeriet (2018c) Udenrigsministeriets Arsrapport 2017. København: Udenrigsministeriet.

Udenrigsministeriet (2018d) "Danmarks kandidatur til FN's menneskerettighedsråd" http://um.dk/da/ Udenrigspolitik/aktuelle-emner/denmark-for-hrc/. 